By DONALD CONEY

\title{
The Flooding Tide
}

\section{Or: Where Did You Go? To the Library. What Did You Get? Nothing.}

$\mathrm{T}$ HE MOST important phenomenon likely to affect our libraries in the near future is a very greatly increased college and university enrollment. ${ }^{1}$ The high birth rate of the 1940's guarantees an unusually large supply of college-age youth by the early 1960's. The rate of increase is enhanced by a general improvement in public health. Our complicated culture, resting on a scientific and technological base, requires a great many people of more than high school education. A prosperous economy supports a rising standard of living, which includes attendance at institutions of higher education. As this was written, in December, it was fashionable in the year-end business reviews, to depreciate our immediate economic future. This, for planning purposes, must be regarded as a short-term condition. Our whole national proclivity is toward continued and increasing prosperity for the growing population. In short, we may expect, unless visited by the dislocations of war or economic catastrophe, that universities-whose libraries we represent-will have to cope very soon and for a long time with steady and very substantial student increases.

The U. S. Office of Education ${ }^{2}$ reported recently that for the sixth consecutive year a new record in college and university enrollments has been established.

1 Address delivered before the University Libraries Section, Chicago, Midwinter Meeting, January 28, 1958. 2 U. S. Department of Health, Education, and Welfare. Office of Education. News release for December $28,1957$.

Mr. Coney is Librarian, University of California, Berkeley.
Four per cent more students had enrolled in colleges and universities in the fall of 1957 than in the fall of 1956. This load is borne unequally; publicly supported institutions gained 6 per cent, whereas privately supported colleges and universities gained only 2 per cent. Liberal arts colleges, teachers colleges, and junior colleges showed the greatest gains, and universities the least. In certain individual institutions, according to a recent Wall Street Journal ${ }^{3}$ survey, a remarkable decline in enrollment is shown. But these are the local groans and rumblings along the fault lines of academic geology. It is not hard to see that a major upthrust to a new plateau of university enrollment is working; as librarians we need to estimate its effects on our establishments.

I work for a university, distinguished among other things for its size. There are certainly disabilities to size, but among its advantages is a self-consciousness about planning. Planning for the current 40,000 students on the eight campuses of the University of California in some ways requires more effort than planning for a lesser number. Certainly, the plan costs a great deal more to realize. Problems which might go unnoticed in a smaller institution become apparent earlier in a larger one. There are more people to pay attention to future problems. Instead of one librarian, the University of California has eight, who are thus able to worry jointly as well as

\footnotetext{
${ }^{3}$ Wall Street Journal, "Campus Paradox," December 26, 1957, p.1.
} 
severally. Furthermore, we exist as a state of the Union and this means that we are continually prodded by state planning agencies. Our State Department of Finance, which prepares the Governor's budget, has been sufficiently concerned about the effect of current population trends on the state's business to employ a resident demographer, whose researches have equipped these state institutions with estimates of enrollment up to 1970. Thus, for us the predicted hordes are not vague in shape, nor very distant. California's population has enlarged by 34 per cent in the seven years since 1950 as against the nation's 13 per cent. ${ }^{4}$ Hagridden by the rise of the college-age population, it is little wonder that the University of California librarians are saddlesore with the problem of enrollment. It has seemed to me that my concern about the effect of a rising student population on the library at Berkeley may suggest useful approaches to this problem on your own campuses, and I offer them to you with regret that they are not more profound.

At Berkeley we have identified six factors, growing out of rising enrollment, which appear to have the greatest effect on library operations and hence call for something explicit in the way of a plan.

Curricular growth. It seems to us important to try to determine where the areas of greatest growth will be in the university curriculum. It appears at Berkeley (and I suspect this will be true in many universities) that there will be increasing emphasis on science and technology. By the same token the humanities will occupy a lesser position-no doubt tertiary-with the social sciences lying somewhere in between. This factor certainly underlines the continuation of a trend. It does, however, result in two effects on library operations: it increases the demand for scientific literature, and

\footnotetext{
4 Wells Fargo Business Review, "Patterns of Popula tion Growth in California," November 29, 1957.
}

by that token emphasizes the importance, in our operations, of the branch library system.

Research and professional education. In our case, it appears probable that there will be increased emphasis on research and on the professional schools. In other words, there will be a redistribution of students upward. This, we believe, will require eventually the development of branch libraries for certain professional schools now happily served by existing branches or in the main building, and this will lead to the need for duplicating materials now shared by many in some central location. It seems certain, too, that there will be greater need for the private reading and work space desirable for the encouragement of graduate study.

Larger faculty. An inevitable concomitant of "more students" is "more faculty." At Berkeley we expect the current 1,050 members of the faculty to rise to 2,110 by 1963 - an increase of over 100 per cent. We all know what effect a new faculty member has on our operations. No matter how well supplied we are with books in his general field, he always imports a new aspect of need and finds the collection inadequate in some degree or other. Men brought into the faculty to augment its variety often find that they must commence to build a collection from nearly the beginning.

Faculty-student ratio. At Berkeley the educational policy of the institution calls for an improvement in the ratio of faculty to students, i.e., fewer students per faculty member. The present ratio is one teacher to twenty students. It is hoped to improve this to a ratio of $1: 12$ or $1: 15$. Such a change, we believe, will have a direct effect on the Library. The possibility of more individual attention from teachers is likely to enliven students' interest in study and lead them to a fuller exploitation of the Library's resources. In some universities this factor will appear in reverse: larger enrollment 
will mean larger classes and greater use of textbooks and the familiar collateral reading of reserve book rooms.

Liberal arts changes. Associated with the foregoing factor at Berkeley is the revamping of our College of Letters and Science educational program. The abolition of a vaguely disreputable program called the "General Curriculum," the addition of an honors program, more rigid scholarship requirements, the encouragement of undergraduates to begin their majors before junior year, the requirement on all to pass a mathematics examination, all these point to an improvement in the quality of undergraduate students and a consequent increase in library use. No doubt similar strengthening of liberal education programs elsewhere-to match the current emphasis on scientific education-will have a similar effect on other libraries.

Size of student body. I have been talking about the ways in which a substantially increased enrollment will affect the educational policy of an institution and its faculty. An influential factor is the student population itself. Although we estimate that the emphasis on research and professional education at the University at Berkeley will bear powerfully on the library organization, we must not neglect the calculation that within, say, the next five years we shall have on the campus between 4,000 and 5,000 more undergraduate students who will not-as graduate and professional students tend to do-distribute themselves over a series of branch libraries, but will work in the commoner materials usually found in a central library building.

These, then, are the factors that appear to be primary in their influence on my library organization. Some of them will certainly be present in your situation; all of them, perhaps, in others. What kind of plan can be derived from such information? It is apparent that the effects of these influences will bear upon, and shape, the book collection, the building program (and, hence, the distribution of the library's collection), upon policy to some extent, and on certain other matters. A part of the plan derivable from such an estimate of the future will be specific and concrete (as in a building program) with quantities and a time scheme explicitly stated. Other parts of the forest are less well mapped, however, and our analysis there will provide us only with a general, dim, soft-focus view of the future (as in the case of the book collection). A plan for developing a book collection is like an academic plan for a university; so much of its unfolding depends on scientific discovery, shifts in society's interest in research, the availability of outstanding persons, and the like, that only a general direction of development can be foreseen. (This is why faculty are always ill housed-except momentarily on the completion of a new building-and why libraries are seldom adequate. Educational policy is intangible and is created instantaneously; buildings and book collections grow with only glacial speed.)

Clearly, the evidence we have supports the assumption that the Library, along with the University, will continue to grow in research and that the mounting enrollment of undergraduates will require the Library to support an extensive teaching program. Since research will be weighted on the side of the sciences, the technologies, and the professions, it is easy to see that our subscription list will increase-thus mortgaging a large part of the book fund in perpetuity. More journals mean an increase in binding expenditure. There is an uncomfortable converse to this axiom. It will become less easy to find compelling arguments for the money needed for monographic materials, in which form humanities literature mostly comes. Certainly the cost of acquiring books for the humanities- 
with their preponderance of interest in retrospective materials - is much higher than the cost of journals and contemporary monographic publications-the form identified with scientific literature. Yet the humanities cannot be slighted in a university - which is by name universal. Indeed, such authorities as President Eisenhower, Vice-President Nixon, and an editorial writer of the New York Times have, since the advent of the Russian satellites, taken pains to emphasize the need for tempering scientific and technological studies with the leavening influence of the humanities. Nevertheless, it will not be easy, we think, to find enough support for this area of study which rests so heavily on a multitude of books, many of which are hard to come by, especially in our new part of the world.

Greater competition between science and other kinds of study is not the only problem foreseen in the book collection field. There is the matter of new territory to be covered. Here the evidence is $\operatorname{dim}$ and we must hark to the twittering of birds and observe the patterns of tea leaves in order to identify subjects of investigation new to us, so that a reasonable amount of anticipatory collecting can be done. In this, as a Columbia professor recently remarked, "pre-vision and enterprise are indispensable."

We must also assume that increasing amounts will be spent not on books themselves, but on copies of books in forms unattractive to the traditionalist but acceptable to the working scholar. We must consider the library's responsibility to the undergraduate and begin to think of what collections are needed to support him in his increasingly difficult task of using a large library system.

Let me pass on to the effect of expansion on policy and certain other matters. Book collecting policy is a term often on our tongues but, like so much planning, more a matter of recording what goes on than a projected scheme of action conscientiously followed. My library, like many, has proceeded on the assumption that it is better to buy a book not already present than to duplicate an existing one. Growing numbers of students and faculty are forcing us to depart from this policy. One specialist in a distant building may be expected to inconvenience himself by walking to the nearest library, but let his specialty come to support, say, five specialists and pressure begins to develop for books closer to home. While this condition is sometimes met by splitting an existing collection, it often can be dealt with only by a certain amount of duplication. Keep in mind that the five scholars of my illustration are as likely to be the result of increased enrollment as they are of any deliberate plan of the university to develop their specialty. Sheer numbers force duplication so that there are enough books to go around. My library has attempted to meet this problem at the undergraduate level by providing a duplicate reserve fund used mainly by the reserve book room. We now look forward to the extension of such duplication to branch libraries, and we expect that the commoner sort of reference tools must be duplicated to meet increased use arising at many points on the campus.

Perhaps the most substantial policy change will be a departure from the view that undergraduates are capable of finding their materials in a library rapidly increasing in size, distribution, and complexity. The need for a greater number of seats than can be provided by extending the main building or the branches, the difficulty undergraduates find in using the Main Library, and the value of supporting the liberal arts curriculum (with its many service courses for professional programs), all point to the wisdom of a special library service for undergraduates, a policy already familiar 
in the Lamont Library and the Undergraduate Library at the University of Michigan.

I come now to the part of planning which deals with the physical development of the library-its quarters: the architecturally enclosed space within which it performs its function. In the matter of physical planning the Library at Berkeley is well integrated with the planning agencies of the campus and of the whole University. Physical planning at Berkeley is largely in the hands of an active and devoted faculty committeethe Buildings and Campus Development Committee-ably assisted by resident architects and operating through a series of specialized subcommittees. It acts as a sensitive plant which picks up intimations of building needs. The Library for the past dozen years has been represented on this committee and, as departmental developments have made the need for buildings known, any relevant library planning has gone forward with the knowledge and assistance of the Library administration. There are, at the moment, six buildings just completed or under construction which contain branch library space. Beginning next year, and in subsequent years, down to 1965-if the schedule holds - are twelve other buildings containing library elements.

Our building program is predicated on three primary factors: (1) an enrollment of 25,000 by 1963 ; (2) an openended collection; and (3) the continued dispersal of research materials between the Main Library building and certain branch libraries. Current estimates indicate that in order to accommodate an enrollment of 25,000 we should have close to 3,000 additional seats in the library system. (Some skepticism has been shown locally of our seating formula, based on our best estimate, which calls for one seat for every four undergraduate, and one for every three graduate students.) Some of these additional seats will be provided in extensions to existing branch library space and in new branches, but approximately 2,000 will remain to be provided otherwise, and this we propose to do by means of a College Library building. This building, if constructed, would provide a physical focus for College of Letters and Science students and lend impressive support to this college's recently adopted program calculated to increase the depth and breadth of the four-year course of study.

A university library's collection is theoretically infinite and, while practical considerations will keep it from attaining this goal, the building plan must accommodate materials which cannot be held in the increasingly valuable space of the main campus. Our plan, therefore, includes an off-campus storage building for important but bulky and infrequently used research materials.

As the sciences and the professional schools develop, their libraries will assume roles of greater and greater importance in the bibliothecal economy of the campus and the increasing bodies of faculty and students who find their primary library satisfactions in these branches will operate to draw more and more books to these locations. For these reasons our building plan includes provision for substantial branch library space.

The staff, the catalog, and the habits of marginal users are all affected by some new branch library combinations. For example, in our case, astronomy, mathematics, and statistics books are soon to be combined in a single library to serve a building jointly occupied by these departments. A new earth sciences building will bring together in a single unit the now separate libraries of the geology, paleontology, and geography departments.

This improvement in branch library facilities will free substantial parts of 
the Main Library building. It is in the redevelopment of this main building space that we expect to find room for more graduate students and faculty in the humanities, history, and certain aspects of the social sciences, and for the expansion of space for newspapers, maps, and government documents. This redevelopment will not come easily. New branch space rides the wave of enthusiasm for a new building, with the intensive support of the department benefited - usually a scientific department or a professional school. The remodelling of existing space is less attractive-after all, the walls are there, the roof dosen't leak, and the values of quiet and privacy are not so apparent as is the necessity for laboratories.

An even more important effect of rising enrollment translated into building space is the dispersive effect on the collection. In our case music and music literature are about to leave our main building, agriculture will follow, as well as the most active parts of the social science collection. When built, the College Library will remove from the main building the reserve book collection.

Not to be neglected is non-library space which may, indirectly, affect the Library. For instance, we believe that our Student Union, to be commenced this summer, and the residence halls, now begun, will increase the concentration of students in the vicinity of the Library and that it will therefore be more used than now.
If you will allow me, I shall offer the view that, in a time of rising enrollment, building space becomes the most important single determinant of a university library's organization. The first question raised about additional enrollment is: Where shall we put the bodies? Buildings are slow to build and expensive. Therefore, their need must be anticipated, and care in their planning must be exercised. They are concrete, specific, real; their financing requires the determination of the number of square feet to be contained within them, of the precise dimensions and proportions of their rooms; their use determines their structure. These specifications compel a library administration to reduce enrollment estimates to seats for readers, to calculate the effect of additional faculty on student behavior toward the library and on the growth of the collection.

The provision of enclosed space is the focus of institutional planning. Space is the planner's coinage, the common denominator to which all physical needs, and most policies, must be reduced. The librarian who neglects the planning machinery - and politics - of his campus will find his library reorganized for him.

In the tidal wave of population universities today are confronted with a phenomenon unprecedented in its effect, and extraordinary in its widespread and early recognition. The storm warnings are up and the flood stages have been? calculated. Don't fail to plan a sturdy and capacious Ark!

\section{A Sum More Than Its Parts}

"Success in this adventure of collegiate instruction seems most likely of reasonable attainment if the student, the professor, and the librarian are thrown into daily contact in such a manner that the sum total of their cooperative endeavors far outstrips the mere addition of their individual accomplishments."-Robert W. Orr in The Library at Iowa State (November 18,1957$)$. 